\title{
Analytical Hierarchy Process Dalam Pemilihan Handphone Android Murah Terbaik
}

\author{
Normah $^{1}$, Bakhtiar Rifai ${ }^{2}$, Hananda Nabil Faras ${ }^{2}$ \\ 1,2,3 Universitas Nusa Mandiri/Informatika \\ e-mail: normah.nor@nusamandiri.ac.id, bakhtiar.bri@nusamandiri.ac.id \\ ${ }^{2}$ Universitas Nusa Mandiri/Sistem Informasi \\ e-mail: hanandafaras@gmail.com
}

\begin{abstract}
Abstrak - Memiliki Handphone kini dianggap sebagai salah satu kebutuhan primer, pasalnya setiap orang hampir memilikinya dari berbagai merek yang terkenal mahal maupun yang murah yakni buatan dari negara cina maupun buatan dari negara lainnya. Dalam membuat suatu keputusan harus melalui banyak pertimbangan, agar tidak membuat keputusan yang sia-sia. Dengan banyaknya pilihan Handphone Android saat ini, membuat masyarakat bingung untuk memilih Handphone Android mana yang cocok untuk digunakan sehari-hari. Penelitian ini bertujuan untuk membuat sistem pendukung keputusan pemilihan Handphone Android dengan menggunakan metode Analytical Hierarchy Process (AHP) yang dapat menyelesaikan masalah dengan cara membandingkan antara Handphone Android Murah yang satu dengan yang lainnya. Kriteria yang digunakan adalah Harga, Ukuran Layar, Chipset, RAM, Kapasitas Internal Storage, Kamera, Kapasitas Baterai, sedangkan sample yang digunakan adalah handphone android yang paling banyak digemari oleh masyarakat menengah kebawah yaitu Samsung A30s, Xiaomi Redmi Note 7, Realme 5i, Oppo A5 2020, dan Vivo Z1 Pro. Hasil dari penelitian ini didapatkan Samsung A30s sebagai Handphone Android Murah yang paling diminati oleh masyarakat menengah kebawah.
\end{abstract}

\section{Keywords: AHP, Handphone, Murah, SPK}

Abstract - Having a mobile phone is now considered as one of the primary needs, because almost everyone has it from various brands that are known to be expensive and cheap, namely those made in China or made in other countries. In making a decision must go through many considerations, so as not to make decisions in vain. With so many choices of Android phones today, it makes people confused about which Android phone is suitable for everyday use. This study aims to create a decision support system for choosing an Android phone using the Analytical Hierarchy Process (AHP) method which can solve the problem by comparing one cheap Android phone with another. The criteria used are Price, Screen Size, Chipset, RAM, Internal Storage Capacity, Camera, Battery Capacity, while the samples used are android phones that are most preferred by the lower middle class, namely Samsung A30s, Xiaomi Redmi Note 7, Realme 5i, Oppo A5 2020, and Vivo Z1 Pro. The results of this study found that the Samsung A30s is the cheapest Android phone that is most in demand by the lower middle class.

Keywords: AHP, Handphone, Cheap, SPK

\section{PENDAHULUAN}

Teknologi komunikasi paling berkembang adalah Handphone. Handphone kini menjadi kebutuhan utama masyarakat dunia dalam berkomunikasi untuk segala usia, baik orangtua, remaja maupun anak anak. Permintaan yang begitu besar membuat perusahaan berlomba-lomba memproduksi handphone dengan berbagai merk dan spesifikasi (Widyasuti, Wanto, Hartama, \& Purwanto, 2017). Banyak bermunculan merek - merek baru di dunia persaingan handphone yang saling berlomba untuk menciptakan produk unggulan mereka. (Amilia,
2017). Kondisi tersebut biasanya sering dialami konsumen ketika ingin mencoba menentukan keputusan dalam membeli sebuah Handphone, sehingga tak heran jika konsumen kadang salah memilih Handphone yang sesuai dengan kebutuhannya dikarenakan kemajemukan tipe, spesifikasinya dan harga yang ditawarkan (Sarifah \& Merlina, 2015).

Salah satu contoh jenis Handphone yang saat ini digemari oleh masyarakat menengah kebawah yaitu dengan menggunakan sistem operasi Android. Banyaknya produk Handphone Android yang 
ditawakan dengan merk, tipe, harga dan spesifikasi yang berbeda, membuat masyrakat terkadang kebingungan dalam memilih produk Handphone Android sesuai dengan kebutuhan dan keinginan (Pieter \& Ramadhani, 2016). Dikarenakan banyaknya Handphone Android murah yang beredar saat ini, penelitian ini mengambil lima seri Handphone Android murah dan tentunya berkualitas yang banyak diminati oleh masyarakat menengah kebawah yaitu Samsung A30s, Xiaomi Redmi Note 7, Realme 5i, Oppo A5 2020, dan Vivo Z1 Pro. Dari lima seri ini, dibuatlah penelitian untuk menentukan Handphone Android murah mana yang lebih cocok dan banyak diminati oleh masyarakat menengah kebawah.

Penelitian ini menggunakan metode Analytical Hierarchi Process (AHP). Metode AHP mampu memecah permasalahan yang kompleks, dan tidak terstruktur menjadi variable dan menatanya dalam bentuk susunan hirarki, kemudian menentapkan variabel mana yang memiliki prioritas paling tinggi (Sanyoto, Handayani, \& Widanengsih, 2017).

Langkah Metode AHP (Gupta \& Vijayvargy, 2021): Langkah 1: Membangun Struktur Hirarki: Masalah harus terstruktur ke dalam hierarki.

Langkah 2: Perbandingan Kriteria

Langkah 3: Perbandingan Sub Kriteria mengenai Kriteria

Langkah 4: Perbandingan Strategi untuk Sub Kriteria

Langkah 5: Mendapatkan Peringkat Keseluruhan: Langkah 6: Sensitivitas Alternatif: menunjukkan bahwa alternatif strategi mana yang terbaik pada kriteria yang berbeda

Sistem pendukung keputusan (SPK) adalah sistem komputer yang mengolah data menjadi informasi untuk mengambil keputusan dari masalah semi terstruktur yang spesifik (Safitri \& Tinus Waruwu, 2017). Sistem pendukung keputusan membantu manajemen menghasilkan alternatif keputusan untuk memecahkan permasalahan terstruktur maupun tidak terstruktur menggunakan data dan model" (Normah, 2018). Beberapa metode yang digunakan dalam menyelesaikan masalah mencari alternatif optimal dari sejumlah alternatif dengan kriteria tertentu yaitu: Simple Additive Weighting Method (SAW), Weighted Product (WP), ELECTRE, Technique for Order Preference by, Similarity to Ideal Solution (TOPSIS), Analytic Hierarchy Process (AHP) (Normah, 2019).

Metode Analytic Hierarchy Process (AHP) melakukan pengambilan keputusan dengan memperhitungkan hal-hal kualitatif dan kuantitatif sekaligus (Putri \& Mahendra, 2019). AHP adalah teknik matematika yang digunakan untuk pengambilan keputusan multi-kriteria (Nilashi,
Bagherifard, Ibrahim, Janahmadi, \& Barisami, 2011). AHP unggul karena mudah dipahami dan fleksibel dalam menyederhanakan permasalahan yang tidak terstruktur dan luas (Normah., Sutomo, \& Rifai, 2021). Dengan menggunakan metode AHP diharapkan dapat membantu pemilihan jenis Smartphone android gaming yang banyak diminati oleh mahasiswa dan layak serta harga yang terjangkau (Rahmatullah, Purnia, \& Hariyadi, 2018).

\section{METODOLOGI PENELITIAN}

Metodologi yang digunakan dalam penelitian ini sebagai berikut :

\section{Identifikasi Masalah}

Pada tahap pertama yang dilakukan mengidentifikasi masalah yang ada. Banyaknya handphone murah yang beredar saat ini membuat masyarakat bingung untuk menentukan handphone mana yang lebih baik untuk digunakan sehari - hari. bagaimana memudahkan masyarakat khususnya menengah kebawah dalam menentukan handphone murah dan tentunya berkualitas untuk digunakan sehari - hari.

\section{Pengumpulan Data}

Sebelum melakukan pengumpulan data, dilakukan observasi terhadap masyarakat menengah kebawah yang ingin membeli sebuah handphone melalui aplikasi Tokopedia. didapatkan 50 (lima puluh) responden yaitu masyarakat menengah kebawah melalui pengisian kuesioner, melalui Google Form. Serta studi kepustakaan dalam menentukan referensi yang didapatkan melalui jurnal - jurnal dan internet untuk mendapatkan teori - teori dari ahli dan pakar. Simple random sampling adalah teknik untuk mendapatkan sampel yang langsung dilakukan pada unit sampling, (Hidayat, 2017).

3. Analisis Data

Pada tahap selanjutnya yaitu menganalisis menggunakan analisis data kuantitatif dan mengolah data yang telah dikumpulkan melalui penyebaran kuesioner dan telah di isi oleh 50 (responden). Dalam mengolah data, menghitung dengan Geometric Mean menggunakan Microsoft Excel dan di cocokan menggunakan Expert Choice V11 untuk mendapatkan hasil penelitian yang akurat. Langkahlangkah implementasi AHP disederhanakan dengan menggunakan perangkat lunak professional Expert Choice (Al-Harbi, 2001).

4. Kesimpulan dan Saran

Kesimpulan dibuat dari hasil analisis dan pengolahan data, serta memberikan saran sebagai usulan terhadap masayarakat menengah kebawah yang ingin memilih handphone murah dan berkualitas untuk digunakan sehari - hari.

\section{HASIL DAN PEMBAHASAN}

Berikut hirarki yang dibuat dengan melihat kriteria dan alternatif yang digunakan: 


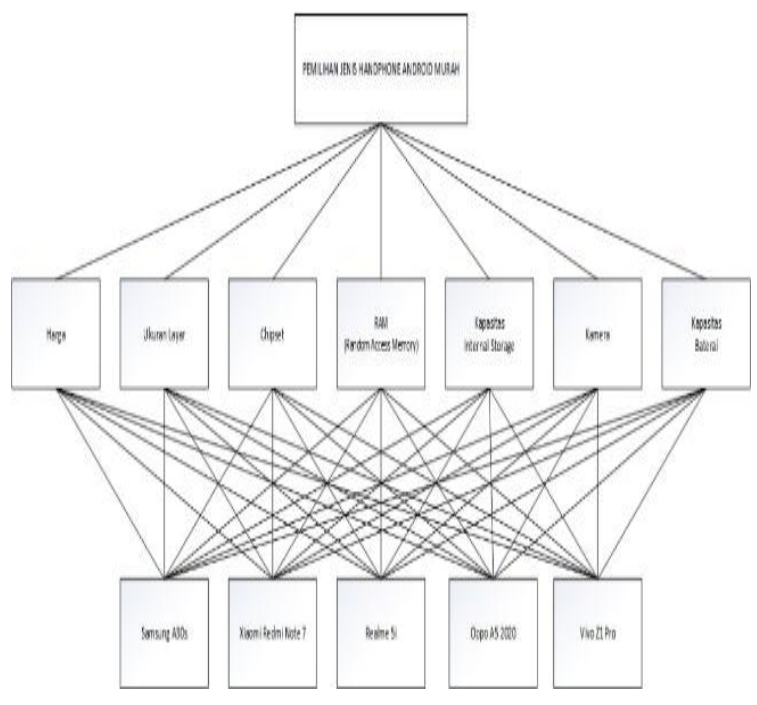

Sumber: (Normah, Bakhtiar, \& Faras, 2021)

Gambar 1. Hirarki Pemilihan Handphone Murah

Dari hasil pengisian kuesioner yang telah di isi oleh 50 responden, maka dibuatlah dalam bentuk matriks perbandingan berpasangan untuk mendapatkan bobot dari kriteria masing - masing. Untuk mempermudah dalam perhitungannya, menggunakan Ms. Excel dan Expert Choice V11. Setiap elemen nya di desimalkan. Berdasarkan matriks perbandingan berpasangan yang telah dibuat, data tersebut diolah untuk memperoleh nilai konsistensi rasio dan indeks konsistensi.

\section{Kriteria Utama}

Nilai pada kolom dibagi dengan jumlah kolom, maka akan diperoleh matriks yang dinormalisasi. Nilai vector eigen didapatkan dari rata - rata bobot relatif untuk setiap baris. Maka hasilnya diperoleh pada tabel di bawah ini :

Tabel 1. Normalisasi Matriks Kriteria Utama

\begin{tabular}{|c|c|c|c|c|c|c|c|c|}
\hline \multicolumn{8}{|c|}{ Normalisasi Kriteria Utama (Eigen) } & \multirow{2}{*}{ 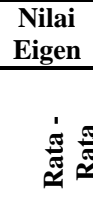 } \\
\hline لِّ & $\underset{3}{\mathbb{E}}$ & 䨔 & 离 & $\sum$ & 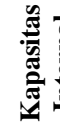 & 莺 & 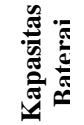 & \\
\hline Harga & $\begin{array}{c}0,3 \\
66\end{array}$ & $\begin{array}{l}0,1 \\
84\end{array}$ & $\begin{array}{l}0,5 \\
34\end{array}$ & $\begin{array}{c}0,4 \\
51\end{array}$ & $\begin{array}{c}0,3 \\
11\end{array}$ & $\begin{array}{l}0,2 \\
24\end{array}$ & $\begin{array}{l}0,2 \\
71\end{array}$ & 0,334 \\
\hline $\begin{array}{l}\text { Ukuran } \\
\text { Layar }\end{array}$ & $\begin{array}{l}0,1 \\
05\end{array}$ & $\begin{array}{l}0,0 \\
52\end{array}$ & $\begin{array}{l}0,0 \\
52\end{array}$ & $\begin{array}{c}0,0 \\
44\end{array}$ & $\begin{array}{c}0,0 \\
30\end{array}$ & $\begin{array}{l}0,0 \\
25\end{array}$ & $\begin{array}{l}0,0 \\
26\end{array}$ & 0,048 \\
\hline Chipset & $\begin{array}{c}0,1 \\
06\end{array}$ & $\begin{array}{l}0,1 \\
57\end{array}$ & $\begin{array}{l}0,1 \\
55\end{array}$ & $\begin{array}{c}0,2 \\
28\end{array}$ & $\begin{array}{c}0,2 \\
49\end{array}$ & $\begin{array}{l}0,1 \\
74\end{array}$ & $\begin{array}{c}0,2 \\
15\end{array}$ & 0,184 \\
\hline RAM & $\begin{array}{c}0,1 \\
06\end{array}$ & $\begin{array}{l}0,1 \\
57\end{array}$ & $\begin{array}{c}0,0 \\
89\end{array}$ & $\begin{array}{c}0,1 \\
31\end{array}$ & $\begin{array}{l}0,2 \\
43\end{array}$ & $\begin{array}{l}0,1 \\
73\end{array}$ & $\begin{array}{c}0,2 \\
09\end{array}$ & 0,159 \\
\hline $\begin{array}{l}\text { Kapasitas } \\
\text { Internal } \\
\text { Storage }\end{array}$ & $\begin{array}{l}0,1 \\
06\end{array}$ & $\begin{array}{l}0,1 \\
57\end{array}$ & $\begin{array}{l}0,0 \\
56\end{array}$ & $\begin{array}{c}0,0 \\
49\end{array}$ & $\begin{array}{l}0,0 \\
90\end{array}$ & $\begin{array}{l}0,1 \\
69\end{array}$ & $\begin{array}{l}0,1 \\
69\end{array}$ & 0,114 \\
\hline
\end{tabular}

\begin{tabular}{lcccccccc}
\hline Kamera & 0,1 & 0,1 & 0,0 & 0,0 & 0,0 & 0,0 & 0,0 & 0,068 \\
& 05 & 36 & 57 & 48 & 34 & 64 & 30 & \\
& & & & & & & & \\
$\begin{array}{l}\text { Kapasitas } \\
\text { Baterai }\end{array}$ & 0,1 & 0,1 & 0,0 & 0,0 & 0,0 & 0,1 & 0,0 & 0,094 \\
\multicolumn{1}{c}{ Total } & 1 & 1 & 1 & 1 & 1 & 1 & 1 & 1 \\
\hline
\end{tabular}

Sumber: (Normah, Bakhtiar, \& Faras, 2021)

Karena nilai $\mathrm{CR} \leq 0,1$, maka dapat diterima atau konsisten. Dari hasil perhitungan pada tabel diatas, menunjukan bahwa Harga merupakan kriteria yang paling penting bagi Pemilihan Handphone Android Murah dengan nilai bobot 0,334 , berikutnya adalah Chipset dengan nilai bobot 0,184 , berikutnya adalah RAM dengan nilai bobot 0,159 , berikutnya adalah Kapasitas Internal Storage dengan nilai bobot 0,114, berikutnya adalah Kapasitas Baterai dengan nilai bobot 0,094, berikutnya adalah Kamera dengan nilai bobot 0,068 , dan yang terakhir adalah Ukuran Layar dengan nilai bobot 0,048 .

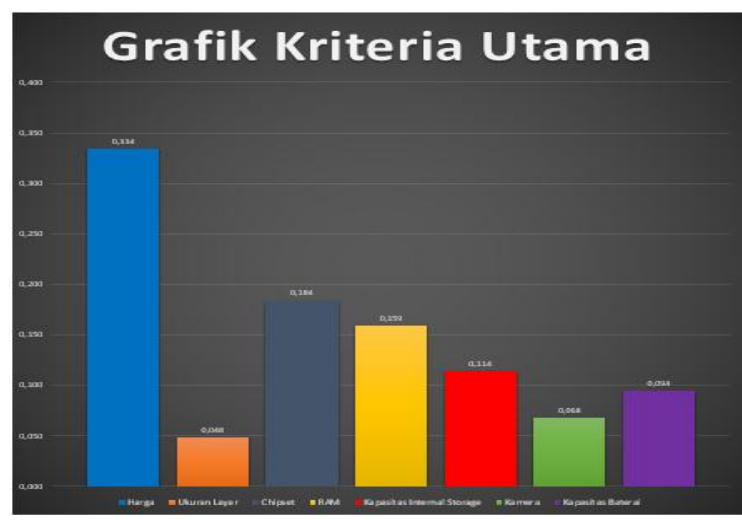

Sumber: (Normah, Bakhtiar, \& Faras, 2021)

Gambar 2. Grafik Kriteria Utama MS.Excel

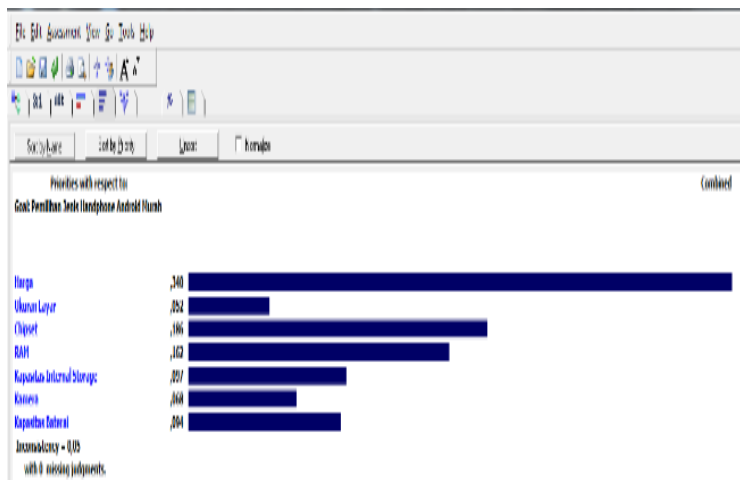

Sumber: (Normah, Bakhtiar, \& Faras, 2021)

Gambar 3. Grafik Kriteria Utama Expert Choice

Berdasarkan grafik dari aplikasi Expert Choice V11, kriteria harga merupakan kriteria yang paling penting pada pemilihan handphone android murah dengan bobot 0,340 , kemudian kriteria chipset dengan bobot 0,186 , kemudian kriteria RAM dengan bobot 0,162 , kemudian kriteria kapasitas internal storage dengan bobot 0,097, kemudian kapasitas baterai dengan bobot 0,094 , kemudian kriteria kamera dengan bobot 0,068 , dan yang terakhir 
kriteria ukuran layar dengan bobot 0,052. Terdapat selisih bobot antara aplikasi Expert Choice V11 dengan Ms. Excel yaitu sebagai berikut :

Tabel 2. Selisih Bobot Kriteria Utama

\begin{tabular}{lccc}
\hline \multicolumn{4}{c}{ Selisih Bobot Kriteria Utama } \\
\hline \multicolumn{1}{c}{ Kriteria } & $\begin{array}{c}\text { Expert } \\
\text { Choice V11 }\end{array}$ & Ms. Excel & Selisih \\
Harga & 0,340 & 0,334 & 0,006 \\
Ukuran Layar & 0,052 & 0,048 & 0,004 \\
Chipset & 0,186 & 0,184 & 0,002 \\
RAM & 0,162 & 0,159 & 0,003 \\
Kapasitas Internal & 0,097 & 0,114 & $-0,017$ \\
Storage & & & 0,000 \\
Kamera & 0,068 & 0,068 & 0,000 \\
Kapasitas Baterai & 0,094 & 0,094 & \\
\hline Sumber: (Normah & & & \\
\hline
\end{tabular}

Sumber: (Normah, Bakhtiar, \& Faras, 2021)

\section{Kriteria Harga}

Tabel 3. Normalisasi Matriks Kriteria Harga

\begin{tabular}{|c|c|c|c|c|c|c|}
\hline \multicolumn{6}{|c|}{ Normalisasi Matriks } & \multirow{2}{*}{ 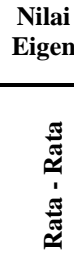 } \\
\hline 藋 & 茛 & 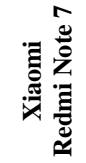 & iñ & 造穴 & $\begin{array}{l}\stackrel{2}{1} \\
\bar{N} \\
\vdots \\
\vdots \\
\vdots\end{array}$ & \\
\hline $\begin{array}{l}\text { Samsung } \\
\text { A30s }\end{array}$ & 0,443 & 0,599 & 0,460 & 0,306 & 0,272 & $\mathbf{0 , 4 1 6}$ \\
\hline $\begin{array}{l}\text { Xiaomi } \\
\text { Redmi } \\
\text { Note } 7\end{array}$ & 0,136 & 0,184 & 0,291 & 0,283 & 0,251 & 0,229 \\
\hline $\begin{array}{l}\text { Realme } \\
\mathbf{5 i}\end{array}$ & 0,136 & 0,090 & 0,142 & 0,258 & 0,233 & $\mathbf{0 , 1 7 2}$ \\
\hline $\begin{array}{l}\text { Oppo A5 } \\
2020\end{array}$ & 0,141 & 0,064 & 0,054 & 0,098 & 0,156 & 0,102 \\
\hline $\begin{array}{l}\text { Vivo Z1 } \\
\text { Pro }\end{array}$ & 0,143 & 0,064 & 0,054 & 0,055 & 0,088 & $\mathbf{0 , 0 8 1}$ \\
\hline Total & 1 & 1 & 1 & 1 & 1 & 1 \\
\hline
\end{tabular}

Sumber: (Normah, Bakhtiar, \& Faras, 2021)

Karena nilai $\mathrm{CR} \leq 0,1$, maka dapat diterima atau konsisten. Dari hasil perhitungan pada tabel diatas, menunjukan bahwa Samsung A30s merupakan jenis Handphone Android Murah yang paling diminati dengan nilai bobot 0,416 , berikutnya adalah Xiaomi Redmi Note 7 dengan nilai bobot 0,229 , berikutnya adalah Realme 5i dengan nilai bobot 0,172 , berikutnya adalah Oppo A5 2020 dengan nilai bobot
0,102, dan yang terakhir adalah Vivo Z1 Pro dengan nilai bobot 0,081 .

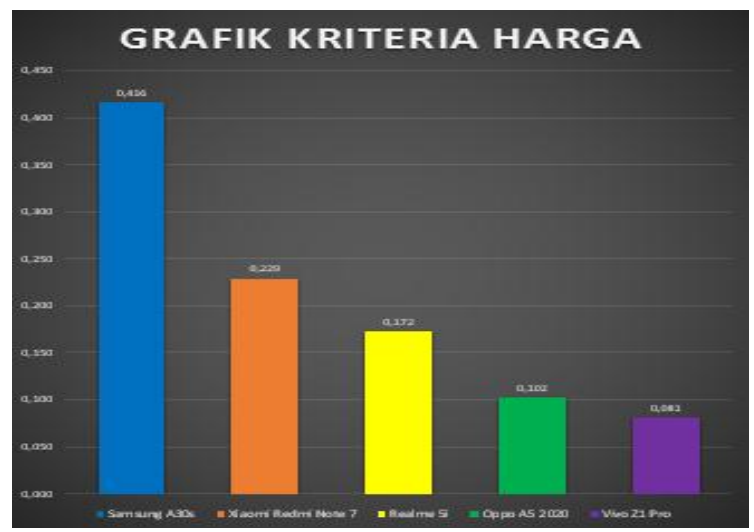

Sumber: (Normah, Bakhtiar, \& Faras, 2021)

Gambar 4. Grafik Kriteria Harga MS. Excel

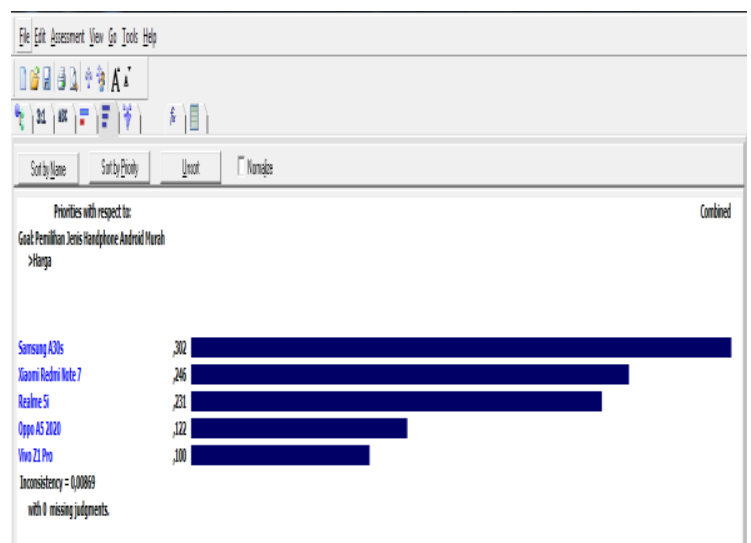

Sumber: (Normah, Bakhtiar, \& Faras, 2021)

\section{Gambar 5. Grafik Kriteria Harga Expert Choice}

Berdasarkan grafik kriteria harga dari aplikasi Expert Choice V11, Samsung A30s merupakan handphone android murah yang paling diminati oleh masyarakat umum dengan bobot 0,302, kemudian Xiaomi Redmi Note 7 dengan bobot 0,246, kemudian Realme 5i dengan bobot 0,231, kemudian Oppo A5 2020 dengan bobot 0,122, dan yang terakhir Vivo Z1 Pro dengan bobot 0,100. Terdapat selisih bobot antara aplikasi Expert Choice V11 dengan Ms. Excel yaitu sebagai berikut :

Tabel 4. Selisih Bobot Kriteria Harga

\section{Kriteria Harga}

\begin{tabular}{lccc}
\hline \multicolumn{1}{c}{ Alternatif } & $\begin{array}{c}\text { Expert Choice } \\
\text { V11 }\end{array}$ & $\begin{array}{c}\text { Ms. } \\
\text { Excel }\end{array}$ & Selisih \\
Samsung A30s & 0,302 & 0,416 & $-0,114$ \\
Xiaomi Redmi Note 7 & 0,246 & 0,229 & 0,017 \\
Realme 5i & 0,231 & 0,172 & 0,059 \\
\hline
\end{tabular}




\begin{tabular}{|c|c|c|c|c|c|c|}
\hline \multicolumn{3}{|c|}{ Oppo A5 2020 } & \multicolumn{2}{|c|}{0,122} & 0,102 & 0,020 \\
\hline \multicolumn{3}{|c|}{ Vivo Z1 Pro } & \multicolumn{2}{|c|}{0,100} & 0,081 & 0,019 \\
\hline \multicolumn{7}{|c|}{ Sumber: (Normah, Bakhtiar, \& Faras, 2021) } \\
\hline \multicolumn{7}{|c|}{ 3. Kriteria Ukuran Layar } \\
\hline \multicolumn{7}{|c|}{$\begin{array}{l}\text { Tabel 5. Normalisasi Matriks Kriteria Ukuran } \\
\text { Layar }\end{array}$} \\
\hline \multicolumn{6}{|c|}{ Normalisasi Matriks } & Nilai \\
\hline 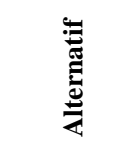 & 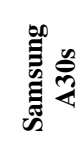 & 泀总 & 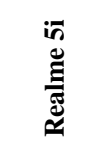 & हैं & $\begin{array}{l}\dot{D} \\
\dot{E} \\
\dot{N} \\
\dot{Z}\end{array}$ & 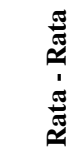 \\
\hline $\begin{array}{l}\text { Samsung } \\
\text { A30s }\end{array}$ & 0,441 & 0,598 & 0,462 & 0,302 & 0,268 & $\mathbf{0 , 4 1 4}$ \\
\hline $\begin{array}{l}\text { Xiaomi } \\
\text { Redmi } \\
\text { Note } 7\end{array}$ & 0,136 & 0,184 & 0,289 & 0,284 & 0,252 & 0,229 \\
\hline $\begin{array}{l}\text { Realme } \\
5 i\end{array}$ & 0,137 & 0,091 & 0,143 & 0,261 & 0,238 & $\mathbf{0 , 1 7 4}$ \\
\hline $\begin{array}{l}\text { Oppo A5 } \\
2020\end{array}$ & 0,142 & 0,063 & 0,053 & 0,097 & 0,154 & 0,102 \\
\hline $\begin{array}{l}\text { Vivo Z1 } \\
\text { Pro }\end{array}$ & 0,144 & 0,064 & 0,053 & 0,055 & 0,088 & $\mathbf{0 , 0 8 1}$ \\
\hline Total & 1 & 1 & 1 & 1 & 1 & 1 \\
\hline
\end{tabular}

Sumber: (Normah, Bakhtiar, \& Faras, 2021)

Karena nilai $\mathrm{CR} \leq 0,1$, maka dapat diterima atau konsisten. Dari hasil perhitungan pada tabel diatas, menunjukan bahwa Samsung A30s merupakan jenis Handphone Android Murah yang paling diminati dengan nilai bobot 0,414 , berikutnya adalah Xiaomi Redmi Note 7 dengan nilai bobot 0,229, berikutnya adalah Realme 5i dengan nilai bobot 0,174 , berikutnya adalah Oppo A5 2020 dengan nilai bobot 0,102, dan yang terakhir adalah Vivo Z1 Pro dengan nilai bobot 0,081 .

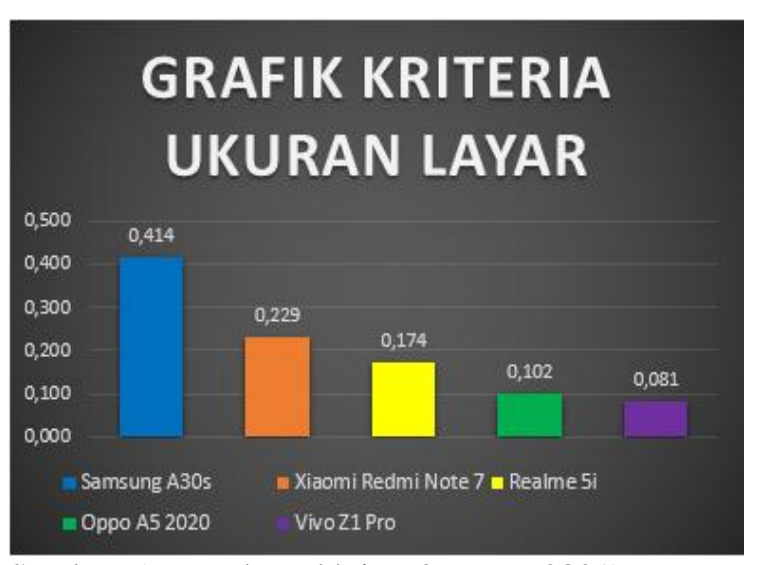

Sumber: (Normah, Bakhtiar, \& Faras, 2021)

Gambar 6. Grafik Kriteria Ukuran Layar MS.
Excel

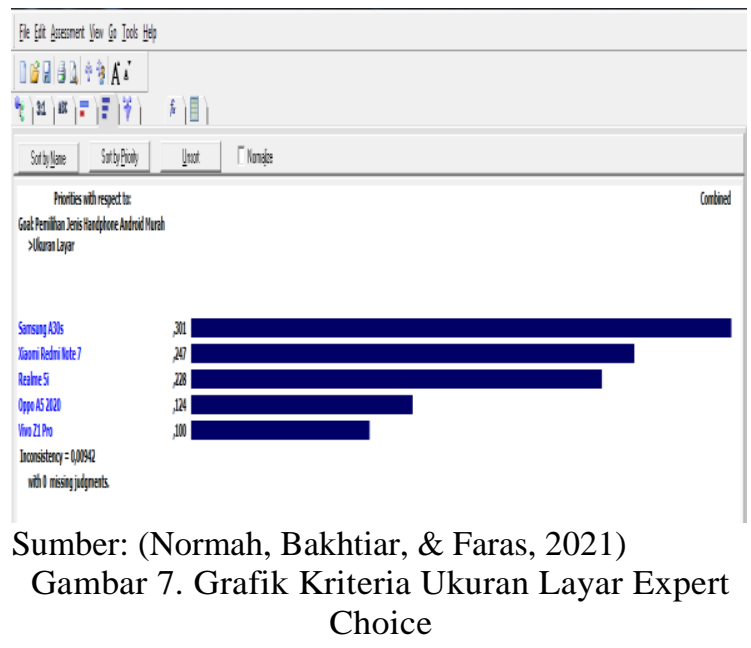

Berdasarkan grafik kriteria ukuran layar dari aplikasi Expert Choice V11, Samsung A30s merupakan handphone android murah yang paling diminati oleh masyarakat umum dengan bobot 0,301 , kemudian Xiaomi Redmi Note 7 dengan bobot 0,247, kemudian Realme 5i dengan bobot 0,228, kemudian Oppo A5 2020 dengan bobot 0,124, dan yang terakhir Vivo Z1 Pro dengan bobot 0,100 . Terdapat selisih bobot antara aplikasi Expert Choice V11 dengan Ms. Excel yaitu sebagai berikut:

Tabel 6. Selisih Bobot Kriteria Ukuran Layar

Kriteria Ukuran Layar

\begin{tabular}{lccc}
\hline \multicolumn{1}{c}{ Alternatif } & $\begin{array}{c}\text { Expert } \\
\text { Choice V11 }\end{array}$ & Ms. Excel & Selisih \\
Samsung A30s & 0,301 & 0,414 & $-0,113$ \\
$\begin{array}{l}\text { Xiaomi Redmi } \\
\text { Note 7 }\end{array}$ & 0,247 & 0,229 & 0,018 \\
Realme 5i & 0,228 & 0,174 & 0,054 \\
Oppo A5 2020 & 0,124 & 0,102 & 0,022 \\
Vivo Z1 Pro & 0,100 & 0,081 & 0,019 \\
\hline Sumber: (Normah, Bakhtiar, \& Faras, 2021) &
\end{tabular}

\section{Kriteria Chipset}

Tabel 7. Normalisasi Mariks Kriteria Chipset

\begin{tabular}{|c|c|c|c|c|c|c|}
\hline \multicolumn{6}{|c|}{ Normalisasi Matriks } & $\begin{array}{l}\text { Nilai } \\
\text { Eigen }\end{array}$ \\
\hline 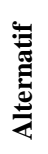 & 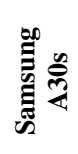 & 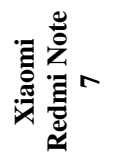 & 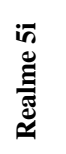 & 告 & 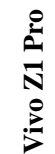 & 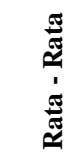 \\
\hline
\end{tabular}




\begin{tabular}{|c|c|c|c|c|c|c|}
\hline $\begin{array}{l}\text { Samsung } \\
\text { A30s }\end{array}$ & 0,441 & 0,599 & 0,462 & 0,301 & 0,266 & 0,414 \\
\hline $\begin{array}{l}\text { Xiaomi } \\
\text { Redmi } \\
\text { Note } 7\end{array}$ & 0,136 & 0,184 & 0,289 & 0,286 & 0,252 & 0,229 \\
\hline $\begin{array}{l}\text { Realme } \\
\mathbf{5 i}\end{array}$ & 0,137 & 0,091 & 0,143 & 0,263 & 0,236 & 0,174 \\
\hline $\begin{array}{l}\text { Oppo A5 } \\
2020\end{array}$ & 0,142 & 0,063 & 0,053 & 0,097 & 0,159 & 0,103 \\
\hline $\begin{array}{l}\text { Vivo Z1 } \\
\text { Pro }\end{array}$ & 0,144 & 0,063 & 0,053 & 0,053 & 0,087 & $\mathbf{0 , 0 8 0}$ \\
\hline Total & 1 & 1 & 1 & 1 & 1 & 1 \\
\hline
\end{tabular}

Sumber: (Normah, Bakhtiar, \& Faras, 2021)

Karena nilai $\mathrm{CR} \leq 0,1$, maka dapat diterima atau konsisten. Dari hasil perhitungan pada tabel diatas, menunjukan bahwa Samsung A30s merupakan jenis Handphone Android Murah yang paling diminati dengan nilai bobot 0,414 , berikutnya adalah Xiaomi Redmi Note 7 dengan nilai bobot 0,229 , berikutnya adalah Realme 5i dengan nilai bobot 0,174 , berikutnya adalah Oppo A5 2020 dengan nilai bobot 0,103 , dan yang terakhir adalah Vivo Z1 Pro dengan nilai bobot 0,080 .

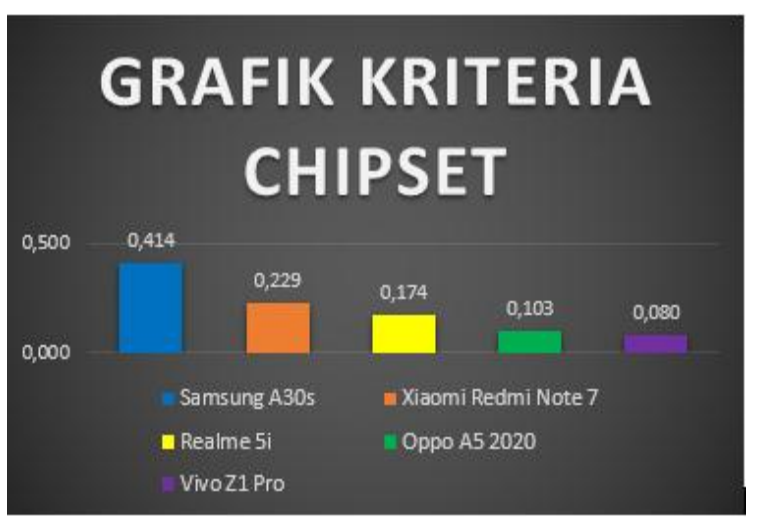

Sumber: (Normah, Bakhtiar, \& Faras, 2021)

Gambar 8. Grafik Kriteria Chipset MS.Excel

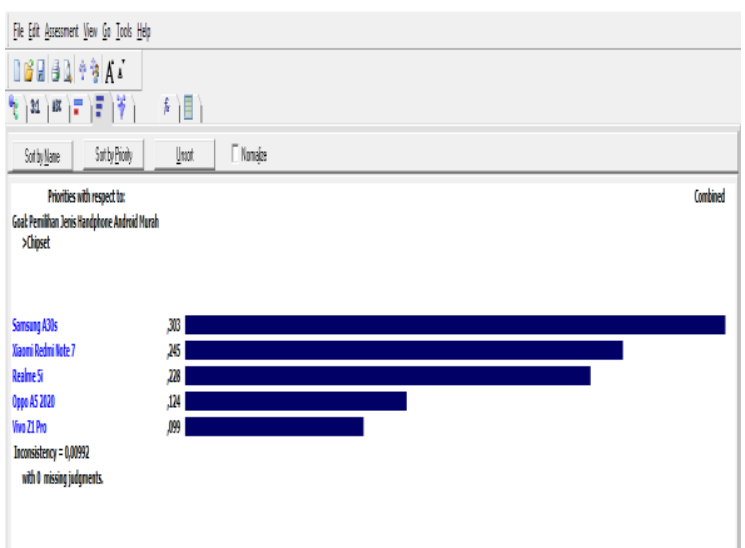

Sumber: (Normah, Bakhtiar, \& Faras, 2021)

Gambar. 9 Grafik Kriteria Chipset Expert Choice
Berdasarkan grafik kriteria chipset dari aplikasi Expert Choice V11, Samsung A30s merupakan handphone android murah yang paling diminati oleh masyarakat umum dengan bobot 0,303 , kemudian Xiaomi Redmi Note 7 dengan bobot 0,245, kemudian Realme 5i dengan bobot 0,228, kemudian Oppo A5 2020 dengan bobot 0,124, dan yang terakhir Vivo Z1 Pro dengan bobot 0,099. Terdapat selisih bobot antara aplikasi Expert Choice V11 dengan Ms. Excel yaitu sebagai berikut :

Tabel 8. Selisih Bobot Kriteria Chipset

Kriteria Chipset

\begin{tabular}{lccc}
\hline \multicolumn{1}{c}{ Alternatif } & $\begin{array}{c}\text { Expert } \\
\text { Choice V11 }\end{array}$ & $\begin{array}{c}\text { Ms. } \\
\text { Excel }\end{array}$ & Selisih \\
Samsung A30s & 0,303 & 0,414 & $-0,111$ \\
Xiaomi Redmi Note 7 & 0,245 & 0,229 & 0,016 \\
Realme 5i & 0,228 & 0,174 & 0,054 \\
Oppo A5 2020 & 0,124 & 0,103 & 0,021 \\
Vivo Z1 Pro & & & \\
& 0,099 & 0,080 & 0,019 \\
\hline Sumber: (Normah, Bakhtiar, \& Faras, 2021) &
\end{tabular}

\section{Kriteria RAM}

Tabel 9. Normalisasi Matriks Kriteria RAM

\begin{tabular}{|c|c|c|c|c|c|c|}
\hline \multicolumn{6}{|c|}{ Normalisasi Matriks } & \multirow{2}{*}{ 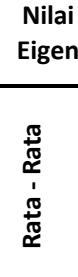 } \\
\hline 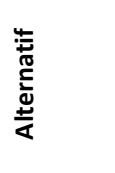 & 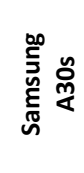 & 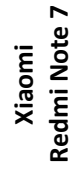 & 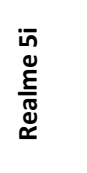 & $\begin{array}{l}\text { 눙 } \\
\text { 융 } \\
\text { 응 }\end{array}$ & 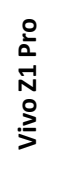 & \\
\hline $\begin{array}{l}\text { Samsung } \\
\text { A30s }\end{array}$ & 0,441 & 0,598 & 0,460 & 0,303 & 0,268 & 0,414 \\
\hline $\begin{array}{l}\text { Xiaomi } \\
\text { Redmi } \\
\text { Note } 7\end{array}$ & 0,136 & 0,184 & 0,291 & 0,282 & 0,250 & 0,228 \\
\hline $\begin{array}{l}\text { Realme } \\
5 \mathbf{i}\end{array}$ & 0,137 & 0,090 & 0,143 & 0,264 & 0,236 & 0,174 \\
\hline $\begin{array}{l}\text { Oppo A5 } \\
2020\end{array}$ & 0,142 & 0,063 & 0,053 & 0,097 & 0,158 & 0,103 \\
\hline $\begin{array}{l}\text { Vivo Z1 } \\
\text { Pro }\end{array}$ & 0,144 & 0,064 & 0,053 & 0,054 & 0,088 & 0,081 \\
\hline Total & 1 & 1 & 1 & 1 & 1 & 1 \\
\hline
\end{tabular}

Sumber: (Normah, Bakhtiar, \& Faras, 2021) 
Karena nilai $\mathrm{CR} \leq 0,1$, maka dapat diterima atau konsisten. Dari hasil perhitungan pada tabel diatas, menunjukan bahwa Samsung A30s merupakan jenis Handphone Android Murah yang paling diminati dengan nilai bobot 0,414 , berikutnya adalah Xiaomi Redmi Note 7 dengan nilai bobot 0,228 , berikutnya adalah Realme 5i dengan nilai bobot 0,174 , berikutnya adalah Oppo A5 2020 dengan nilai bobot 0,103, dan yang terakhir adalah Vivo Z1 Pro dengan nilai bobot 0,081 .

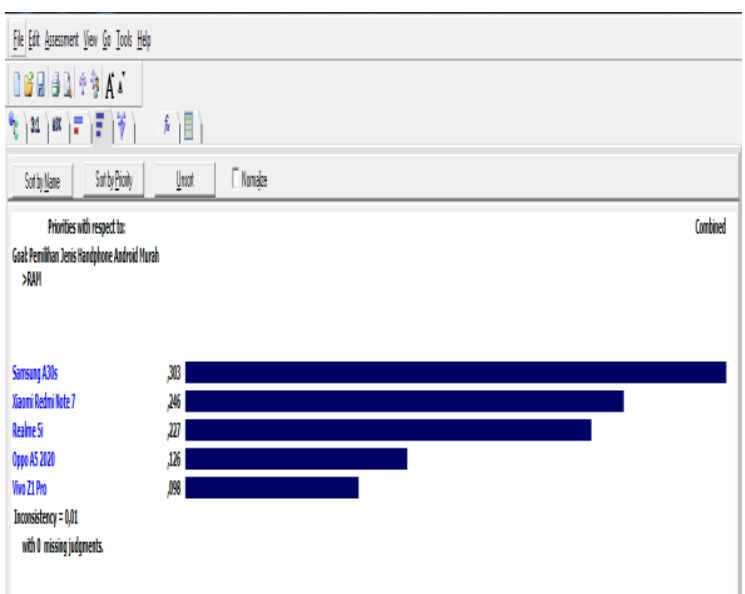

Sumber: (Normah, Bakhtiar, \& Faras, 2021)

Gambar 10. Grafik Kriteria RAM Expert Choice

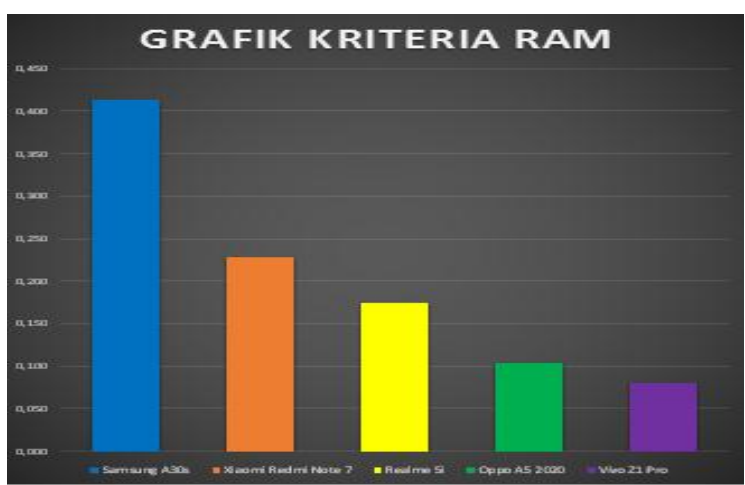

Sumber: (Normah, Bakhtiar, \& Faras, 2021)

Gambar 11. Grafik Kriteria RAM MS. Excel

Berdasarkan grafik kriteria RAM dari aplikasi Expert Choice V11, Samsung A30s merupakan handphone android murah yang paling diminati oleh masyarakat umum dengan bobot 0,303, kemudian Xiaomi Redmi Note 7 dengan bobot 0,246, kemudian Realme 5i dengan bobot 0,227, kemudian Oppo A5 2020 dengan bobot 0,126, dan yang terakhir Vivo Z1 Pro dengan bobot 0,098. Terdapat selisih bobot antara aplikasi Expert Choice V11 dengan Ms. Excel yaitu sebagai berikut :
Tabel 10. Selisih Bobot Kriteria RAM

Kriteria RAM

\begin{tabular}{lccc}
\hline \multicolumn{1}{c}{ Alternatif } & $\begin{array}{c}\text { Expert } \\
\text { Choice V11 }\end{array}$ & $\begin{array}{c}\text { Ms. } \\
\text { Excel }\end{array}$ & Selisih \\
Samsung A30s & 0,303 & 0,414 & $-0,111$ \\
Xiaomi Redmi Note 7 & 0,246 & 0,228 & 0,018 \\
Realme 5i & 0,227 & 0,174 & 0,053 \\
Oppo A5 2020 & 0,126 & 0,103 & 0,023 \\
Vivo Z1 Pro & 0,098 & 0,081 & 0,017 \\
\hline
\end{tabular}

Sumber: (Normah, Bakhtiar, \& Faras, 2021)

\section{Kriteria Kapasitas Internal Storage}

Tabel 11. Normalisasi Kriteria Kapasitas Internal Storage

\begin{tabular}{|c|c|c|c|c|c|c|}
\hline \multicolumn{6}{|c|}{ Normalisasi Matriks } & \multirow{2}{*}{ 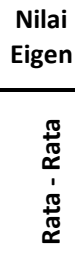 } \\
\hline 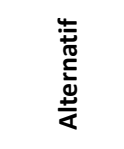 & 象 & 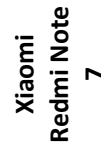 & 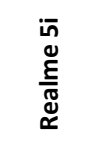 & 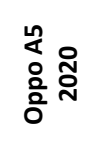 & $\begin{array}{l}0 \\
\frac{1}{2} \\
-1 \\
0 \\
\vdots \\
\vdots\end{array}$ & \\
\hline $\begin{array}{l}\text { Samsung } \\
\text { A30s }\end{array}$ & 0,441 & 0,598 & 0,460 & 0,303 & 0,268 & 0,414 \\
\hline $\begin{array}{l}\text { Xiaomi } \\
\text { Redmi } \\
\text { Note } 7\end{array}$ & 0,136 & 0,184 & 0,291 & 0,283 & 0,250 & 0,229 \\
\hline $\begin{array}{l}\text { Realme } \\
5 i\end{array}$ & 0,137 & 0,090 & 0,143 & 0,262 & 0,236 & 0,174 \\
\hline $\begin{array}{l}\text { Oppo A5 } \\
2020\end{array}$ & 0,142 & 0,063 & 0,053 & 0,098 & 0,158 & 0,103 \\
\hline $\begin{array}{l}\text { Vivo Z1 } \\
\text { Pro }\end{array}$ & 0,144 & 0,064 & 0,053 & 0,054 & 0,088 & 0,081 \\
\hline Total & 1 & 1 & 1 & 1 & 1 & 1 \\
\hline
\end{tabular}

Sumber: (Normah, Bakhtiar, \& Faras, 2021)

Karena nilai $\mathrm{CR} \leq 0,1$, maka dapat diterima atau konsisten. Dari hasil perhitungan pada tabel diatas, menunjukan bahwa Samsung A30s merupakan jenis Handphone Android Murah yang paling diminati dengan nilai bobot 0,414 , berikutnya adalah Xiaomi Redmi Note 7 dengan nilai bobot 0,229 , berikutnya adalah Realme 5i dengan nilai bobot 0,174 , berikutnya adalah Oppo A5 2020 dengan nilai bobot 0,103, dan yang terakhir adalah Vivo Z1 Pro dengan nilai bobot 0,081 . 


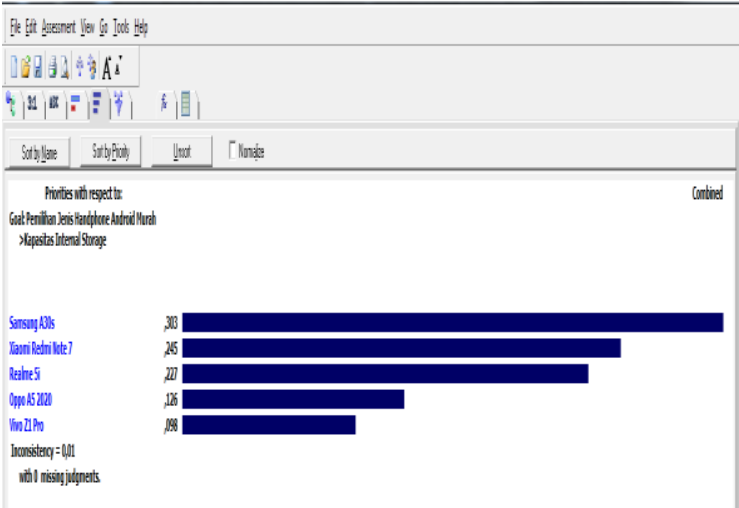

Sumber: (Normah, Bakhtiar, \& Faras, 2021)

Gambar 12. Grafik Kriteria Kapasitas Internal Storage Expert Choice

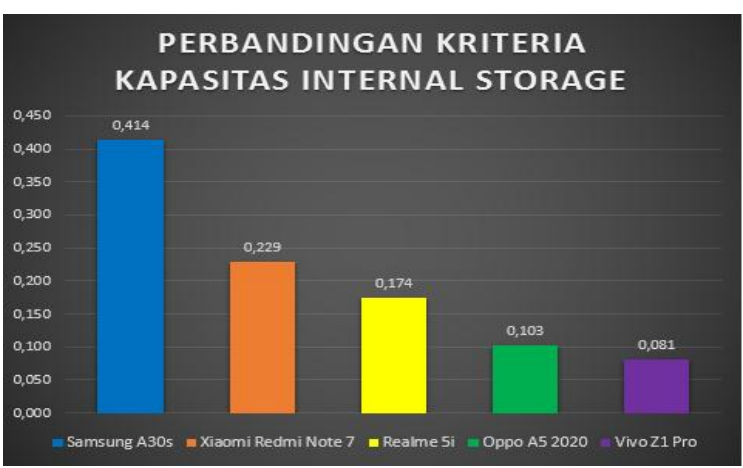

Sumber: (Normah, Bakhtiar, \& Faras, 2021)

Gambar 13. Grafik Kriteria Kapasitas Internal Storage MS.Excel

Berdasarkan grafik kriteria kapasitas internal storage dari aplikasi Expert Choice V11, Samsung A30s merupakan handphone android murah yang paling diminati oleh masyarakat umum dengan bobot 0,303, kemudian Xiaomi Redmi Note 7 dengan bobot 0,245, kemudian Realme 5i dengan bobot 0,227, kemudian Oppo A5 2020 dengan bobot 0,126, dan yang terakhir Vivo Z1 Pro dengan bobot 0,098. Terdapat selisih bobot antara aplikasi Expert Choice V11 dengan Ms. Excel yaitu sebagai berikut:

Tabel 12. Selisih Bobot Kriteria Kapasitas Internal Storage

Kriteria Kapasitas Internal Storage

\begin{tabular}{lccc}
\hline \multicolumn{1}{c}{ Alternatif } & $\begin{array}{c}\text { Expert } \\
\text { Choice V11 }\end{array}$ & $\begin{array}{c}\text { Ms. } \\
\text { Excel }\end{array}$ & Selisih \\
Samsung A30s & 0,303 & 0,414 & $-0,111$ \\
Xiaomi Redmi Note 7 & 0,245 & 0,229 & 0,016 \\
Realme 5i & 0,227 & 0,174 & 0,053 \\
Oppo A5 2020 & 0,126 & 0,103 & 0,023 \\
\hline
\end{tabular}

\begin{tabular}{llll}
\hline Vivo Z1 Pro & 0,098 & 0,081 & 0,017
\end{tabular}

Sumber: (Normah, Bakhtiar, \& Faras, 2021)

\section{Kriteria Kamera}

Tabel 13. Normalisasi Matriks Kriteria Kamera

\begin{tabular}{|c|c|c|c|c|c|c|}
\hline \multicolumn{6}{|c|}{ Normalisasi Matriks } & \multirow{2}{*}{ 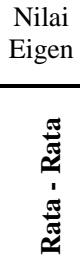 } \\
\hline 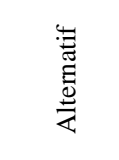 & 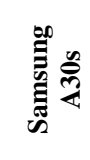 & م & 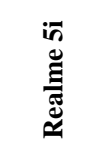 & 옹 & $\begin{array}{l}\dot{D} \\
\bar{N} \\
\dot{B} \\
\dot{J}\end{array}$ & \\
\hline $\begin{array}{l}\text { Samsung } \\
\text { A30s }\end{array}$ & 0,442 & 0,597 & 0,465 & 0,303 & 0,267 & 0,415 \\
\hline $\begin{array}{l}\text { Xiaomi } \\
\text { Redmi } \\
\text { Note } 7\end{array}$ & 0,136 & 0,183 & 0,285 & 0,282 & 0,249 & 0,227 \\
\hline $\begin{array}{l}\text { Realme } \\
5 \mathrm{i}\end{array}$ & 0,136 & 0,092 & 0,143 & 0,264 & 0,235 & $\mathbf{0 , 1 7 4}$ \\
\hline $\begin{array}{l}\text { Oppo } \\
\text { A5 } 2020\end{array}$ & 0,142 & 0,063 & 0,053 & 0,098 & 0,161 & 0,104 \\
\hline $\begin{array}{l}\text { Vivo Z1 } \\
\text { Pro }\end{array}$ & 0,144 & 0,064 & 0,053 & 0,053 & 0,087 & $\mathbf{0 , 0 8 0}$ \\
\hline Total & 1 & 1 & 1 & 1 & 1 & 1 \\
\hline
\end{tabular}

Sumber: (Normah, Bakhtiar, \& Faras, 2021)

Karena nilai $\mathrm{CR} \leq 0,1$, maka dapat diterima atau konsisten. Dari hasil perhitungan pada tabel diatas, menunjukan bahwa Samsung A30s merupakan jenis Handphone Android Murah yang paling diminati dengan nilai bobot 0,415 , berikutnya adalah Xiaomi Redmi Note 7 dengan nilai bobot 0,227, berikutnya adalah Realme $5 \mathrm{i}$ dengan nilai bobot 0,174 , berikutnya adalah Oppo A5 2020 dengan nilai bobot 0,104, dan yang terakhir adalah Vivo Z1 Pro dengan nilai bobot 0,080 .

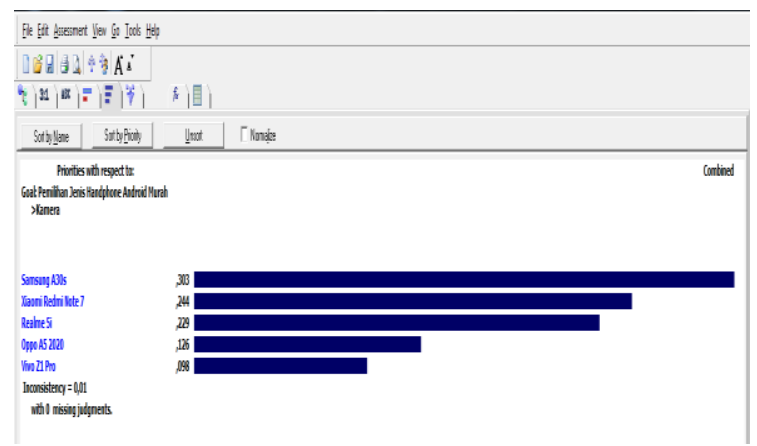

Sumber: (Normah, Bakhtiar, \& Faras, 2021) Gambar 14. Grafik Kriteria Kamera Expert Choice 


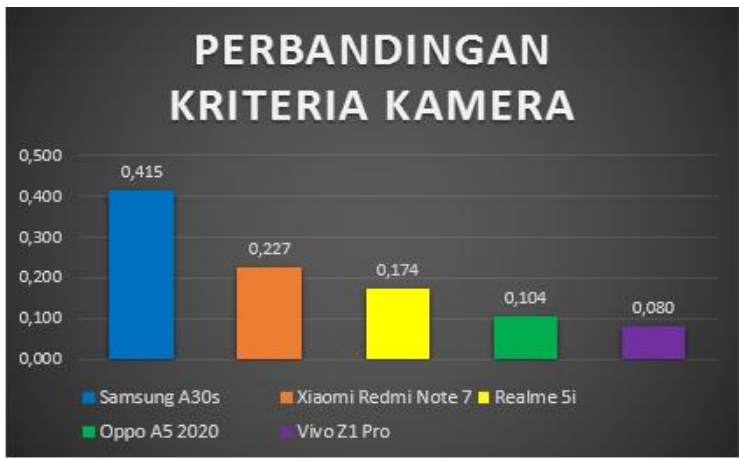

Sumber: (Normah, Bakhtiar, \& Faras, 2021)

Gambar 15. Grafik Kriteria Kamera MS.Excel

Berdasarkan grafik kriteria kamera dari aplikasi Expert Choice V11, Samsung A30s merupakan handphone android murah yang paling diminati oleh masyarakat umum dengan bobot 0,303, kemudian Xiaomi Redmi Note 7 dengan bobot 0,244, kemudian Realme 5i dengan bobot 0,229, kemudian Oppo A5 2020 dengan bobot 0,126, dan yang terakhir Vivo Z1 Pro dengan bobot 0,098. Terdapat selisih bobot antara aplikasi Expert Choice V11 dengan Ms. Excel yaitu sebagai berikut :

Tabel 14. Selisih Bobot Kriteria Kamera

\begin{tabular}{|c|c|c|c|c|c|c|}
\hline \multicolumn{7}{|c|}{ Kriteria Kamera } \\
\hline \multicolumn{2}{|c|}{ Alternatif } & \multicolumn{2}{|c|}{$\begin{array}{c}\text { Expert } \\
\text { Choice V11 }\end{array}$} & $\begin{array}{l}\text { Ms. } \\
\text { Excel }\end{array}$ & \multicolumn{2}{|c|}{ Selisih } \\
\hline \multicolumn{3}{|c|}{ Samsung A30s } & 0,303 & \multicolumn{2}{|c|}{0,415} & $-0,112$ \\
\hline \multicolumn{3}{|c|}{ Xiaomi Redmi Note 7} & 0,244 & \multicolumn{2}{|c|}{0,227} & 0,017 \\
\hline \multicolumn{3}{|l|}{ Realme 5i } & 0,229 & \multicolumn{2}{|c|}{0,174} & 0,055 \\
\hline \multicolumn{3}{|c|}{ Oppo A5 2020} & 0,126 & \multicolumn{2}{|c|}{0,104} & 0,022 \\
\hline \multicolumn{3}{|c|}{ Vivo Z1 Pro } & 0,098 & \multicolumn{2}{|c|}{0,080} & 0,018 \\
\hline \multicolumn{7}{|c|}{ Sumber: (Normah, Bakhtiar, \& Faras, 2021) } \\
\hline \multicolumn{7}{|c|}{ 8. Kriteria Baterai } \\
\hline \multicolumn{7}{|c|}{$\begin{array}{l}\text { Tabel 15. Normalisasi Matriks Kriteria Kapasitas } \\
\text { Baterai }\end{array}$} \\
\hline \multicolumn{6}{|c|}{ Normalisasi Matriks } & $\begin{array}{c}\text { Nilai } \\
\text { Eigen }\end{array}$ \\
\hline 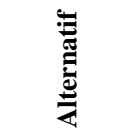 & 彎 & 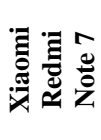 & 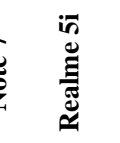 & 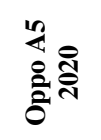 & $\begin{array}{l}\bar{N} \\
\stackrel{2}{Z}\end{array}$ & 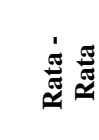 \\
\hline $\begin{array}{l}\text { Samsung } \\
\text { A30s }\end{array}$ & 0,442 & 0,597 & 0,463 & 0,305 & 0,269 & 0,415 \\
\hline $\begin{array}{l}\text { Xiaomi } \\
\text { Redmi } \\
\text { Note } 7\end{array}$ & 0,136 & 0,183 & 0,288 & 0,282 & 0,249 & 0,227 \\
\hline
\end{tabular}

\begin{tabular}{|c|c|c|c|c|c|c|}
\hline $\begin{array}{l}\text { Realme } \\
\text { 5i }\end{array}$ & 0,136 & 0,091 & 0,143 & 0,261 & 0,235 & $\mathbf{0 , 1 7 3}$ \\
\hline $\begin{array}{l}\text { Oppo A5 } \\
2020\end{array}$ & 0,142 & 0,064 & 0,054 & 0,098 & 0,159 & 0,103 \\
\hline $\begin{array}{l}\text { Vivo Z1 } \\
\text { Pro }\end{array}$ & 0,144 & 0,065 & 0,053 & 0,054 & 0,088 & 0,081 \\
\hline Total & 1,000 & 1,000 & 1,000 & 1,000 & 1,000 & 1,000 \\
\hline
\end{tabular}

Sumber: (Normah, Bakhtiar, \& Faras, 2021)

Karena nilai $\mathrm{CR} \leq 0,1$, maka dapat diterima atau konsisten. Dari hasil perhitungan pada tabel diatas, menunjukan bahwa Samsung A30s merupakan jenis Handphone Android Murah yang paling diminati dengan nilai bobot 0,415 , berikutnya adalah Xiaomi Redmi Note 7 dengan nilai bobot 0,227 , berikutnya adalah Realme $5 \mathrm{i}$ dengan nilai bobot 0,173 , berikutnya adalah Oppo A5 2020 dengan nilai bobot 0,103, dan yang terakhir adalah Vivo Z1 Pro dengan nilai bobot 0,081 .

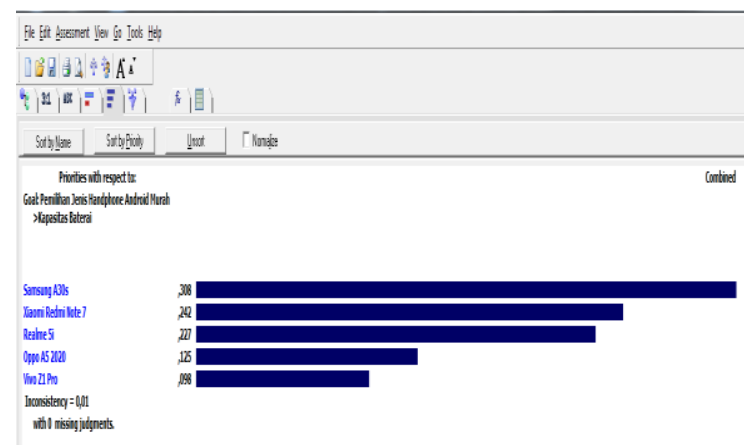

Sumber: (Normah, Bakhtiar, \& Faras, 2021)

Gambar 16. Grafik Kriteria Baterai Expert Choice

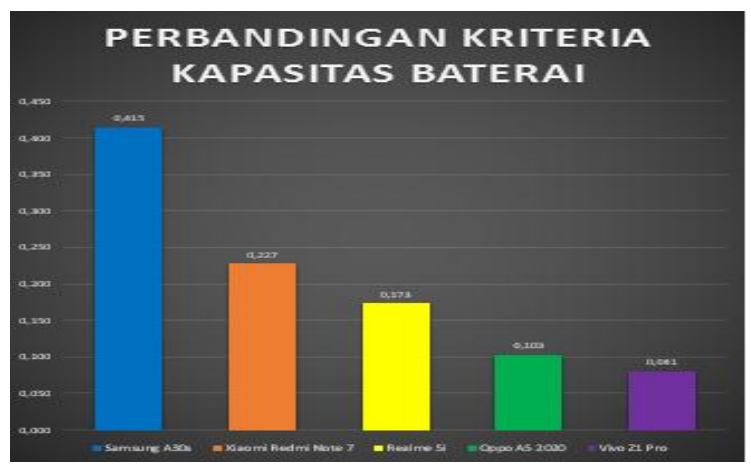

Sumber: (Normah, Bakhtiar, \& Faras, 2021)

Gambar 17. Grafik Kriteria Baterai MS.Excel

Berdasarkan grafik kriteria kapasitas baterai dari aplikasi Expert Choice V11, Samsung A30s merupakan handphone android murah yang paling diminati oleh masyarakat umum dengan bobot 0,303, kemudian Xiaomi Redmi Note 7 dengan bobot 0,244, kemudian Realme 5i dengan bobot 0,229, kemudian Oppo A5 2020 dengan bobot 0,126, dan yang terakhir Vivo Z1 Pro dengan bobot 0,098. Terdapat selisih bobot antara aplikasi Expert Choice V11 dengan Ms. Excel yaitu sebagai berikut: 
Tabel 16. Selisih Bobot Kriteria Baterai

\begin{tabular}{lccc}
\multicolumn{4}{c}{ Kriteria Kapasitas Baterai } \\
\hline \multicolumn{1}{c}{ Alternatif } & $\begin{array}{c}\text { Expert } \\
\text { Choice } \\
\text { V11 }\end{array}$ & $\begin{array}{c}\text { Ms. } \\
\text { Excel }\end{array}$ & Selisih \\
Samsung A30s & 0,308 & 0,415 & $-0,107$ \\
Xiaomi Redmi Note 7 & 0,242 & 0,227 & 0,015 \\
Realme 5i & 0,227 & 0,173 & 0,054 \\
Oppo A5 2020 & 0,125 & 0,103 & 0,022 \\
Vivo Z1 Pro & 0,098 & 0,081 & 0,017 \\
\hline Sumber: (Normah, Bakhtiar, \& Faras, 2021) &
\end{tabular}

Sumber: (Normah, Bakhtiar, \& Faras, 2021)

\section{Hasil Akhir}

Untuk menentukan hasil akhir dari masing - masing alternatif pemilihan handphone android murah yaitu dengan cara mengalikan nilai eigen masing - masing alternatif dengan nilai eigen kriteria utama.

Tabel 17. Nilai Eigen Alternatif

\section{Nilai Eigen Alternatif}

\begin{tabular}{|c|c|c|c|c|c|c|c|}
\hline 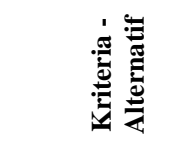 & 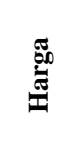 & 壱 & 苋 & $\sum$ & 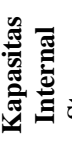 & 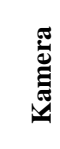 & 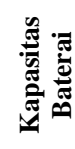 \\
\hline Samsung A30s & 0,4 & 0,4 & 0,4 & 0,4 & $\begin{array}{r}0,4 \\
14\end{array}$ & $\begin{array}{r}0,4 \\
15\end{array}$ & \\
\hline & & & & 14 & 14 & 15 & 15 \\
\hline $\begin{array}{l}\text { Xiaomi Redmi } \\
\text { Note } 7\end{array}$ & $\begin{array}{l}0,2 \\
29\end{array}$ & $\begin{array}{l}0,2 \\
29\end{array}$ & $\begin{array}{l}0,2 \\
29\end{array}$ & $\begin{array}{l}0,2 \\
28\end{array}$ & $\begin{array}{c}0,2 \\
29\end{array}$ & $\begin{array}{l}0,2 \\
27\end{array}$ & \\
\hline Realme 5i & 0,1 & 0,1 & 0,1 & 0,1 & 0,1 & 0,1 & 0,1 \\
\hline & 72 & 74 & 74 & 74 & 74 & 74 & \\
\hline Oppo A5 2020 & 0,1 & 0,1 & 0,1 & 0,1 & 0,1 & 0,1 & ), \\
\hline & 02 & 02 & 03 & 03 & 03 & 04 & \\
\hline ivo & 0,0 & 0,0 & 0 , & 0 & 0,0 & 0,0 & \\
\hline & 81 & 81 & 80 & 81 & 81 & 80 & \\
\hline
\end{tabular}

Sumber: (Normah, Bakhtiar, \& Faras, 2021)

Tabel 18. Nilai Eigen Kriteria Utama

Nilai Eigen Kriteria Utama

\begin{tabular}{cc}
\hline Harga & 0,334 \\
Ukuran Layar & 0,048 \\
Chipset & 0,184 \\
\hline
\end{tabular}

\begin{tabular}{cc}
\hline RAM & 0,159 \\
Kapasitas Internal Storage & 0,114 \\
Kamera & 0,068 \\
Kapasitas Baterai & 0,094 \\
\hline
\end{tabular}

Sumber: (Normah, Bakhtiar, \& Faras, 2021)

Berdasarkan nilai eigen keputusan, bahwa prioritas bobot tertinggi yaitu Samsung A30s dengan bobot 0,415. Dapat disimpulkan bahwa masyarakat umum lebih memilih Samsung A30s sebagai handphone android murah terbaik. Disusul dengan Xiaomi Redmi Note 7 dengan bobot 0,229, kemudian Realme 5i dengan bobot 0,173 , kemudian Oppo A5 2020 dengan bobot 0,103 , dan yang terakhir adalah Vivo Z1 Pro dengan bobot 0,081 .

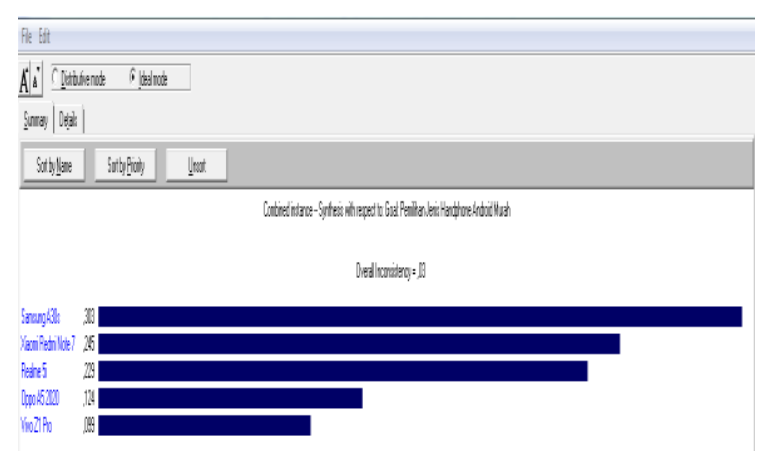

Sumber: (Normah, Bakhtiar, \& Faras, 2021)

Gambar 18. Grafik Hasil Akhir Expert Choice

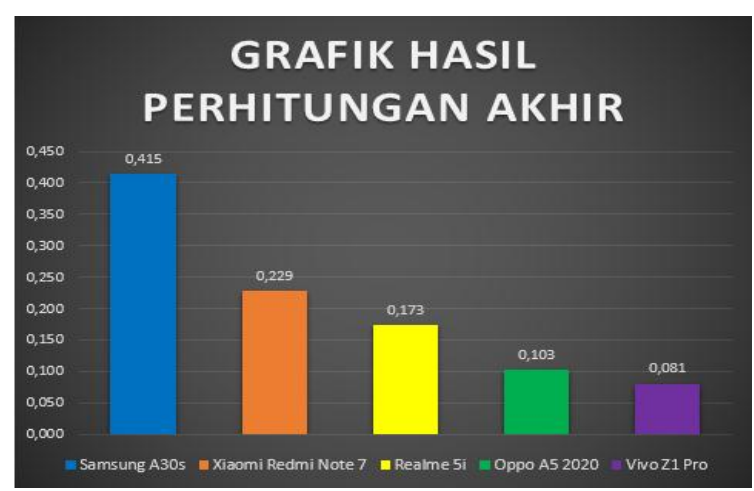

Sumber: (Normah, Bakhtiar, \& Faras, 2021)

Gambar 19. Grafik Hasil Akhir

Berdasarkan hasil perhitungan akhir dari aplikasi Expert Choice V11, Samsung A30s merupakan handphone android murah yang paling diminati oleh masyarakat umum dengan bobot 0,303, kemudian Xiaomi Redmi Note 7 dengan bobot 0,245, kemudian Realme 5i dengan bobot 0,229, kemudian Oppo A5 2020 dengan bobot 0,124, dan yang terakhir Vivo Z1 Pro dengan bobot 0,099. Terdapat selisih bobot antara aplikasi Expert Choice V11 dengan Ms. Excel yaitu sebagai berikut : 
Tabel 19. Selisih Hasil Akhir

Selisih Hasil Perhitungan Akhir

\begin{tabular}{lccc}
\hline \multicolumn{1}{c}{ Alternatif } & $\begin{array}{c}\text { Expert } \\
\text { Choice V11 }\end{array}$ & $\begin{array}{c}\text { Ms. } \\
\text { Excel }\end{array}$ & Selisih \\
Samsung A30s & 0,303 & 0,415 & $-0,112$ \\
Xiaomi Redmi Note 7 & 0,245 & 0,229 & 0,016 \\
Realme 5i & 0,229 & 0,173 & 0,056 \\
Oppo A5 2020 & 0,124 & 0,103 & 0,021 \\
Vivo Z1 Pro & 0,099 & 0,081 & 0,018 \\
& & & \\
\hline Sumber: (Normah, Bakhtiar, \& Faras, 2021) &
\end{tabular}

Sumber: (Normah, Bakhtiar, \& Faras, 2021)

\section{KESIMPULAN}

Berdasarkan hasil analisa yang dilakukan, maka dapat diambil kesimpulan sebagai berikut:

1. Dalam pengambilan keputusan, metode AHP sangat cocok digunakan. Karena metode ini memperlihatkan perbandingan antara kriteria yang satu dengan yang lainnya terhadap alternatif.

2. Dengan menggunakan metode AHP, mempermudah dalam pengambilan suatu keputusan, karena berdasarkan kriteria dan alternatif yang dibuat menjadi suatu hirarki.

3. Hasil dari penelitian ini didapatkan Samsung A30s sebagai Handphone Android Murah yang paling diminati oleh masyarakat menengah kebawah.

\section{REFERENSI}

Al-Harbi, K. M. A.-S. (2001). Application Of The AHP In Project Management. International Journal of Project Management, 19(1), 19-27. https://doi.org/https://doi.org/10.1016/S02637863(99)00038-1

Amilia, S. (2017). Pengaruh Citra Merek , Harga , dan Kualitas Produk terhadap Keputusan Pembelian Handphone Merek Xiaomi di Kota Langsa. Jurnal Manajemen Dan Keuangan, 6(1), 660-669.

Gupta, S., \& Vijayvargy, L. (2021). Selection of Green Supplier in Automotive Industry: An Expert Choice Methodology. IOP Conference Series: Earth and Environmental Science, 795(1). 1315/795/1/012036

Hidayat, A. (2017). Teknik Sampling Dalam Penelitian (Penjelasan Lengkap) - Uji Statistik.
Nilashi, M., Bagherifard, K., Ibrahim, O., Janahmadi, N., \& Barisami, M. (2011). An Application Expert System for Evaluating Effective Factors on Trust in B2C WebsitesTrust, Security, ANFIS, Fuzzy Logic, Rule Based Systems, Electronic Commerce. Engineering, 03(11), 1063-1071. https://doi.org/10.4236/eng.2011.311132

Normah., Sutomo, D., \& Rifai, B. (2021). Analytical Hierarchy Process Dalam PemilihanVSAT BUC (Block Up Converter) Berdasarkan Kualitas Produk. INTI Nusa Mandiri, 15(2), 171-176.

https://doi.org/https://doi.org/10.33480/inti.v1 $5 \mathrm{i} 2.2015$

Normah. (2018). Simple Additive Weighting Dalam Penentuan Rekomendasi Kenaikan Jabatan Karyawan. Teknik Informatika; STMIK Nusa Mandiri Jakarta, 3(1), 21-32.

Normah. (2019). Fuzzy Simple Additive Weighting Dalam Sistem Penyeleksian Anggota Forum Penerima Beasiswa Orbit. INFORMATICS FOR EDUCATORS AND PROFESSIONALS, 3(2), 109-118.

Normah, Bakhtiar, R., \& Faras, H. N. (2021). Analytical Hierarchy Process Dalam Pemilihan Handphone Android Murah Terbaik.

Pieter, M. S. S., \& Ramadhani, L. T. (2016). Sistem Pendukung Keputusan Pemilihan Handphone Android Menggunakan Metode Analytical Hierarchy Process. Teknologi Informasi, 4(2), $1-13$.

Putri, P. K., \& Mahendra, I. (2019). Implementasi Metode Analytical Hierarchy Process ( Ahp ) Dalam Sistem Pendukung Keputusan Pembelian Rumah Di Kota Tangerang. Jurnal Teknoinfo, 13(1), 37-38. Retrieved from https://ejurnal.teknokrat.ac.id/index.php/teknoi nfo/article/view/238/157

Rahmatullah, S., Purnia, D. S., \& Hariyadi, R. (2018). Sistem Pendukung Keputusan Pemilihan Smartphone Android Gaming dengan Metode Analytical Hierarchy Process. Jurnal Kajian Ilmiah Universitas Bhayangkara Jakarta Raya, 18(3), 294-306.

Safitri, K., \& Tinus Waruwu, F. (2017). SISTEM PENDUKUNG KEPUTUSAN PEMILIHAN KARYAWAN BERPRESTASI DENGAN MENGGUNAKAN METODE ANALYTICAL HIEARARCHY PROCESS (Studi Kasus : PT.Capella Dinamik Nusantara Takengon). 1(1), 12-16.

Sanyoto, G. P., Handayani, R. I., \& Widanengsih, E. (2017). Sistem Pendukung Keputusan Pemilihan Laptop Untuk Kebutuhan Operasional Dengan Metode Ahp ( Studi Kasus: Jurnal Pilar Nusa Mandiri, 13(2), 167-174. https://doi.org/ISSN: 2303-11

Sarifah, \& Merlina, N. (2015). SISTEM 
PENUNJANG KEPUTUSAN PEMILIHAN HANDPHONE MENGGUNAKAN METODE ANALYTICAL HIERARCHY PROCESS. Jurnal Pilar Nusa Mandiri, XI(1), 90-99.

https://doi.org/10.1364/cleo.2010.jthe97

Widyasuti, M., Wanto, A., Hartama, D., \& Purwanto, E. (2017). Rekomendasi Penjualan Aksesoris Handphone Menggunakan Metode Analitycal Hierarchy Process (AHP). Konferensi Nasional Teknologi Informasi Dan Komputer, 1(1), 27-32.

\section{PROFIL PENULIS}

Penulis pertama Normah, memperoleh gelar M.Kom, Jurusan Ilmu Komputer pada Sekolah Tinggi Manajemen Informatika dan Komputer Nusa Mandiri, lulus tahun 2014. Saat ini menjadi Dosen di Universitas Nusa Mandiri (S1) program studi Informatika.

Penulis kedua Bakhtiar Rifai, memperoleh gelar M.Kom, Jurusan Ilmu Komputer pada Sekolah Tinggi Manajemen Informatika dan Komputer Nusa Mandiri, lulus tahun 2013. Saat ini menjadi Dosen di Universitas Nusa Mandiri (S1) program studi Informatika.

Penulis kedua Hananda Nabil Faras, memperoleh gelar S.Kom, Jurusan Sistem Informasi pada Sekolah Tinggi Manajemen Informatika dan Komputer Nusa Mandiri, lulus tahun 2020. 